\title{
GEOMORPHOLOGICAL EFFECTS OF RIVER VALLEYS ANTHROPOGENIC TRANSFORMATIONS IN THE PERZNICA CATCHMENT DURING THE LAST 200 YEARS (DRAWSKO LAKELAND, PARSĘTA RIVER BASIN)
}

\author{
JóZEF SZPIKOWSKI \\ Adam Mickiewicz University, Institute of Geoecology and Geoinformation, Poznań, Poland
}

Manuscript received: November 20, 2010

Revised version: February 21, 2011

\begin{abstract}
SzPIKOWSк J., 2011. Geomorphological effects of river valleys anthropogenic transformations in the Perznica catchment during the last 200 years (Drawsko Lakeland, Parsęta river basin). Quaestiones Geographicae 30(1), Bogucki Wydawnictwo Naukowe, Poznań, pp. 105-114, 4 Figs., 2 Tabs. ISBN 978-83-62662-39-5. ISSN 0137-477X. DOI 10.2478/v10117-011-0010-4.

AвSTRACT. The studies on geomorphological aspects of environmental changes in the river valleys were part of the work carried out under the diagnosis of anthropogenic transformation of the relief of the Perznica basin (West Pomerania, Drawsko Lakeland). Human interference in the river valleys and anthropogenic changes in the natural hydrological systems in the Perznica catchment influenced the transformation of the relief and the intensity of morphogenetic processes. Numerous anthropogenic landforms were formed, including embankments, dams, dykes along the canals, ditches and canals, reservoirs basins, and peat excavations. The drainage resulted in an intensification of the river erosion, straightening, shortening and increase of the river gradient, as well as the increase of quantity of the suspended matter leaving the catchments. An increase of anthropogenic denudation on agricultural lands, due to the entering of the crops grown on drained depressions and valleys, led to the masking of the original relief with deluvial sediments and the formation and expansion of agricultural terraces on the edge of the fields.
\end{abstract}

KEYWORDS: anthropogenic denudation, anthropogenic transformation of river valleys, disappearance of mid-field depressions, drainage in valleys and on slopes, Drawsko Lakeland

Józef Szpikowski, Adam Mickiewicz University, Institute of Geoecology and Geoinformation, Department of Geoecology, Dzięgielowa 27, 61-680 Poznań, Poland, e-mail szpiko@amu.edu.pl

\section{Introduction}

An anthropopressure on the geographic environment is reflected in a particular way in the changes occurring in river valleys. In moderate climate conditions, a matter outflow from a catchment via river channels is the most important element in circulation of energy and matter in a geoecosystem (Kostrzewski 1986, 1993). Hu- man interference in river valleys directly affects the size and dynamics of flow in channels and drains from the catchments (Kostrzewski et al. 1994, Gutry-Korycka 1999). It leads to changes in hydrological regime.

Human activity in the valleys often changes a river profile and increases aggradation or erosion in river channels (Gonera et al. 1985, Florek 1993). Such changes are of high importance for 
the functioning of slopes and the whole morphogenetic system.

Stability disturbance of slopes has its implications for the relief development of flat areas and plateaux, even the ones very distant from river valleys (Rachlewicz et al. 2008). Human interference in river valleys is often associated with the disturbance of water conditions (Ciupa 2009). Both the raising and the lowering of groundwater level in valleys brings hydrological and geomorphological consequences far beyond the zone of river valleys.

The first important anthropogenic changes of the geographical environment in the river valleys of Central Pomerania are associated with the construction of water mills. An improvement of agricultural techniques during medieval colonisations influenced yield growth by an average of $30-60 \%$, and in some areas up to $100 \%$ (Piskorski 1990). Increase of grain production entailed the development of water mills, known in Pomerania since the $12^{\text {th }}$ century (Piskorski 1990, Podgórski 2004). Their dissemination in West Pomerania started in the $13^{\text {th }}$ century. The great water mill in Koszalin was elevated at that time, and functioned from 1289 (Brüggemann 1784). The analysis of the Lubinus map indicates that the water mills were not present in the Perznica catchment until 1618 (Lubinus 1618). However, some other mills existed in its neighborhood: on an upper section of the Parsęta River near the Parsęcko village, on the upper Chociel River prior to the city of Bobolice, and on the Gwda River between the lakes Drężno and Wierzchowo. According to Gilly (1789), there were seven water mills in the Perznica catchment by the end of the $18^{\text {th }}$ century.

Major irrigation works were initiated in the middle of the $18^{\text {th }}$ century in the West Pomerania within the confines of so-called fryderycjanska colonisation. The largest projects in the north-eastern Poland included: the regulation of the lower Odra River from the year 1776, regulation of the Płonia River and lakes Miedwie and Płoń, commenced in 1770, failure of the regulations of the Łeba River and Łebsko Lake in the years 1780-82, drainage of wetlands between Kamień Pomorski and Trzebiatowo, which started in 1775, and the reduction of water level of Trzesiecko and Wielimie lakes in the years 1780-1782 (Szultka 2003).
A series of hydraulic works on the rivers of Pomerania, forced by an increasing flood risk, were undertaken in the second half of the nineteenth century and early twentieth century (Hesse 1999, Florek et al. 2008a, Florek et al. 2008b). An introduction of the law on private water management (Privatsflussgestz) in 1843 was a major impulse for the implementation of numerous smaller projects (Malinowski 2006). It allowed landowners to create partnerships which were engaged in the drainage works in wetlands, regulation of rivers and lowering the water level in lakes.

The studies regarding the geomorphological aspects of changes in the river valleys were part of the work carried out to diagnose the anthropogenic transformation of the Perznica basin relief (Szpikowski 2010).

\section{Study area}

Study area - the Perznica catchment - is located within the area of $249 \mathrm{~km}^{2}$ in the north-western Poland, in the central part of the Drawsko Lakeland (Fig. 1), which belongs to the macroregion of West Pomeranian Lakeland (Kondracki 1998). The relief is considerably diverse (denivelation of $160 \mathrm{~m}$ ) due to the location in several subzones of the Parsęta lobe. It is characteristic for this part of the marginal zone of the Pomeranian phase of Vistulian glaciation (Karczewski 1989). Several subzones can be distinguished:

- the subzone of internal kame moraine - the undulated moraine upland diversified by kame forms and kettle holes,

- the subzone of ice-free areas forms with the kame plateaux hills - in places under the ice surface elevation,

- the subzone of melt-out lake basin - the Wielatowo Lake basin with characteristic 'collar' ridge,

- the morphological levels of the northern Pomeranian sloping surface - mainly flat moraine uplands and small outwash planes.

The rivers of the Perznica catchment use genetically diverse network of valleys. Some of them are former subglacial channels, e.g. the Perznica River valley west from the Trzebiechowo Lake (Dobracka \& Lewandowski 2002). In some sections the rivers flow in deep, v-shaped 
valleys, with morphological characteristics of young Holocene gaps (such as the Perznica River valley south of the Sławno village, so called Wet Ravine). Many river valleys in the Perznica basin use the system of meltwater drainage routes today. This applies, above all, to the rivers in the central and western part of the Perznica catchment.

Landscape of the relief and the location in the north-eastern part of the Parsęta lobe, make most of the rivers in the Perznica catchment flow from northeast to southwest, or east to west. According to the Polish hydrological division (1986), the Perznica River is the main watercourse, with a length of $24.3 \mathrm{~km}$ (according to the topographic map in scale 1:10,000). The river spring lies in the
Krągłe village, at an altitude of 165 meters a.s.l. Through the smaller streams, the Perznica River also drains the Wielatowo Lake basin area. The greatest right-bank tributaries of the Perznica River are: the Trzebiegoszcz River (length of 27.2 $\mathrm{km})$, the Radusza River $(20.6 \mathrm{~km})$, and the Łozica River $(18.4 \mathrm{~km})$. The only significant tributary in the south is the Graniczny Rów River, which drains water from the surrounding villages: Storkowo, Wielawino and Lubogoszcz.

The river network density index, reflecting the current stage of organization and development of the hydrographic network, has a value of $2.17 \mathrm{~km} \mathrm{~km}^{-2}$ for permanent streams for the whole area of the Perznica catchment. The lake index is $1.79 \%$ and varies for different parts of

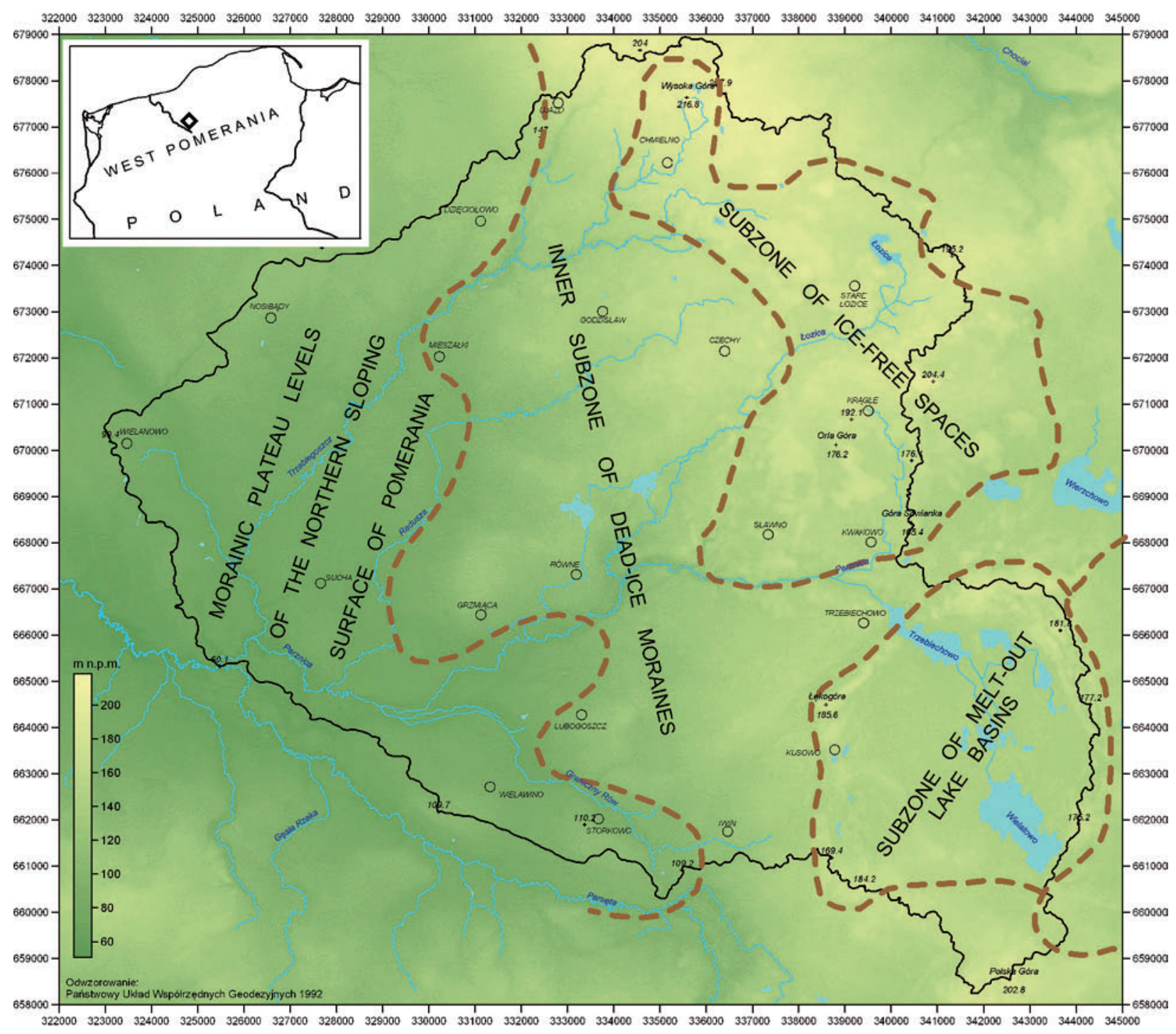

Fig. 1. Location of the study area on the background of the Pomeranian Phase subzones within the Parsęta lobe, after A. Karczewski (1989) 
the research area. The majority of big surface water bodies is grouped in the melt-out basin Wielatowo Lake. The biggest among them is Wielatowo Lake, with an area of $1.79 \mathrm{~km}^{2}$, average depth $2.5 \mathrm{~m}$, and maximum depth $4.7 \mathrm{~m}$. The next biggest, Trzebiechowo Lake, covers an area of $0.86 \mathrm{~km}^{2}$, with an average depth of 3.5 , and maximum depth of $8 \mathrm{~m}$ (surface lakes from the topographic map in scale 1:10,000 and depth according to Choiński 1991). Other smaller water bodies of the Wielatowo Lake basin are: Jeziorki Lake $\left(0.26 \mathrm{~km}^{2}\right)$, Kople Lake $\left(0.14 \mathrm{~km}^{2}\right)$ and the anthropogenic ponds near the Brzeźno village $\left(0.19 \mathrm{~km}^{2}\right)$. In the north-eastern part of the catchment lies Łozice Lake $\left(0.25 \mathrm{~km}^{2}\right)$, and in the central, the artificial reservoirs Baczyno $\left(0.24 \mathrm{~km}^{2}\right)$ and Baczynko $\left(0.19 \mathrm{~km}^{2}\right)$. Altogether, there are 558 reservoirs in the Perznica catchment, $92 \%$ of them being small ponds, mostly of the melt-out origin, and with an area of less than $0.005 \mathrm{~km}^{2}$ each. The water bodies, regardless of their area, demonstrate various degrees of overgrowth and of filling with the mineral-organic sediments. The process of disappearance of lakes in a postglacial landscape is confirmed by Galon (1954), who indicates that the Middle Pomerania experienced a loss of more than $2 / 3$ of former lakes. On the other hand, the idea concerning permanent tendency to decline of the small, melt-out water bodies over the past 100-200 years (Pieńkowski 1996), has not found a confirmation in the case of the Perznica catchment. Even without taking into account the data derived from the 130 years old archival maps, which can be criticized for having little accuracy, in the 1930s only $60 \%$ of small ponds existed in the Perznica catchment, in comparison with the 1980s. That missing part, then drained and consequently converted into meadows or marshes, now returned to its original landscape role because of a failure to discharge excess water. The rivers in the Perznica catchment, similar to other Pomeranian rivers, are characterized by a low variability of runoff, which is a result of the large underground recharge (up to $77 \%$ ), infiltration increased because of the presence of large amounts of surface depressions, and retention of the catchment increased by lakes and marsh-peatland areas (Dynowska 1971, Choiński 1998). The average runoff in the Pomerania, from Połczyn Zdrój to Kartuzy, is the highest in the Polish Lowlands and amounts to $10-15 \mathrm{dm}^{3} \mathrm{~s}^{-1}$ $\mathrm{km}^{-2}$ (Kozłowski 1994).

\section{Material and methods}

Among the research methods employed, the use of archival maps should be noted above all as an important source concerning the changes in the river network system and human interference in the valleys. For the purpose of analysis, all available large scale maps for this part of Pomerania were used (Table 1). The Elihard Lubinus map (1618) contains serious projection

Table 1. The archival cartographic materials used in studies in the Perznica catchment

\begin{tabular}{|c|c|c|c|c|c|}
\hline Name & $\begin{array}{c}\text { Author/ } \\
\text { editor }\end{array}$ & Year & Map sheets & Scale & Source \\
\hline $\begin{array}{c}\text { Great Map of Po- } \\
\text { meranian Principal- } \\
\text { ity }\end{array}$ & Elihard Lubinus & 1618 & - & $1: 240,000$ & $\begin{array}{c}\text { Regional Museum in } \\
\text { Szczecinek }\end{array}$ \\
\hline $\begin{array}{c}\text { Karte des Konigl. } \\
\text { Preus. Herzogthums } \\
\text { Vor. und Hinter. } \\
\text { Pommern }\end{array}$ & $\begin{array}{c}\text { D. Gilly/ D. F. Sotz- } \\
\text { mann }\end{array}$ & 1789 & III, VI & $1: 180,000$ & $\begin{array}{c}\text { Adam Mickiewicz Uni- } \\
\text { versity, Main Library }\end{array}$ \\
\hline $\begin{array}{c}\text { Generalstabskarte } \\
\text { Prussian Kingdom }\end{array}$ & około 1855 & 125,126 & $1: 100,000$ & $\begin{array}{c}\text { Adam Mickiewicz Uni- } \\
\text { versity, Main Library }\end{array}$ \\
\hline $\begin{array}{c}\text { topographic map } \\
\text { Messtischblätter }\end{array}$ & $\begin{array}{c}\text { Prussia Office of } \\
\text { State Images }\end{array}$ & 1877 & $\begin{array}{c}695,696,780,781, \\
782,875,876\end{array}$ & $1: 25,000$ & $\begin{array}{c}\text { Adam Mickiewicz Uni- } \\
\text { versity, Main Library }\end{array}$ \\
\hline $\begin{array}{c}\text { geological and soil } \\
\text { map }\end{array}$ & $\begin{array}{c}\text { Royal Prussia State } \\
\text { Geological Institute }\end{array}$ & 1893 & $\begin{array}{c}695,696,780,781, \\
782,875,876\end{array}$ & $1: 25,000$ & $\begin{array}{c}\text { Adam Mickiewicz Uni- } \\
\text { versity, Main Library }\end{array}$ \\
\hline $\begin{array}{c}\text { topographic map } \\
\text { Messtischblätter }\end{array}$ & $\begin{array}{c}\text { Reich Office of State } \\
\text { Images }\end{array}$ & 1935 & $\begin{array}{c}2164,2165,2264, \\
2164,265\end{array}$ & $1: 25,000$ & own collection \\
\hline
\end{tabular}


errors, and therefore lacks cartometric values. The map, however, provides a lot of important data, among other things, about the settlement network, the forest coverage and the existence of water mills.

The process of rectification and georeferention to the State Coordinate System 1965 was conducted for the remaining maps. It employs methods of choice of local check points (Pietrzak 2005) and automatic resampling process (in computer programme TNTmips v. 6.4, Microimages Inc's, USA). The 1986 topographic map sheets in 1:10,000 scale, issued by the Head Office of Geodesy and Cartography in Warsaw were used as primary maps. Eventually, all maps were resampled to the State Geodetic Coordinate System 1992, obligatory from year 2010. For such prepared cartographic materials vectorisation of the spatial objects was carried out. The final step was to prepare the digital maps of land cover and land use, which include any type of line objects. Content analysis of the archival maps and the comparative study conducted on the numerical maps made it possible to identify the changes in the river valleys of the Perznica catchment in the last two centuries.

The important stage of the field investigation included the morphological mapping and lithological reconnaissance of the chosen sites. In the whole Perznica catchment drillings were performed within the slopes and plateaux in the places where relief transformation caused by the implementation of farming in wetland areas of the former midfield depressions was expected. GPS Leica System 500 receiver was used to measure the morphology of the fields. The lithology diagnosis was made using hand-held drilling, soil pits and sampling of biogenic sediments using a Instorf sampler.

\section{The transformations in river valleys and lake basins}

The largest anthropogenic transformation of natural hydrological systems in the Perznica catchment, is the construction of the irrigation system in Grzmiąca village area (Fig. 2). The need for watering meadows and arable lands situated on the slopes and valley bottoms was related to the progressing drying caused by the decrease of groundwater level, a consequence of regulating the river channels and digging the drainage ditches. Depletion of water resources as a result of drainage and following transformation of soil, peat surface loss and changes in plants are frequently occurring in Poland (e.g. Wodziczko 1947, Pietrucień 1993, Marcinek \& Komisarek 2004). The process of excessive hydrogenic and semihydrogenic soil desiccation advanced quickly in the Perznica catchment, especially on the outwash plains and in the valleys. It was caused by the increasing range of regulatory and drainage works in the valleys, from the late eighteenth and nineteenth century. The scale of drainage projects is especially visible in the increase of density of the river network, also including ditches (Table 2). Attempts were made to counteract the adverse effects of drainage in the Middle Pomerania, as evidenced by the remains of irrigation systems, such as the ones in the Radew River valley near Kurowo, in the Parsęta River valley below Krosino, or in the Chotla River valley, east of Bukowo (the archival topographic maps from the 1930s). Nowadays, they are most often out of order and largely filled with sediment artificial channels, which run in parallel to the rivers, and drain part of the waters to the valley adjacent slopes.

The drainage system near the village of Grzmiąca was constructed before the middle of the nineteenth century, and expanded in the subsequent years. After the swelling of waters in the Łozica River (right-bank tributary of the Perznica River), they were directed by channels to the natural depressions, transformed through a relatively small excavation into the basins of water reservoirs. As a result of this work, two water reservoirs arose (the Baczyno and Baczynko Lakes, German name Bewässerungs Bassin I and II) with an area of, respectively, 0.19 and $0.23 \mathrm{~km}^{2}$. The consequence of the reservoirs placement in a hummocky landscape of dead ice moraine, is a varied coastline including the small islands and,

Table 2. The indicators of the Perznica catchment river network in the years 1855-1986

\begin{tabular}{|l|c|c|c|c|}
\hline \multicolumn{1}{|c|}{ Year } & $\mathbf{1 8 5 5}$ & $\mathbf{1 8 7 7}$ & $\mathbf{1 9 3 5}$ & $\mathbf{1 9 8 6}$ \\
\hline $\begin{array}{l}\text { length of rivers } \\
{[\mathrm{km}]}\end{array}$ & 173,7 & 433,3 & 585,2 & 540,5 \\
\hline $\begin{array}{l}\text { density of river network } \\
{\left[\mathrm{km} \mathrm{km}^{-2}\right]}\end{array}$ & 0,7 & 1,7 & 2,3 & 2,2 \\
\hline
\end{tabular}




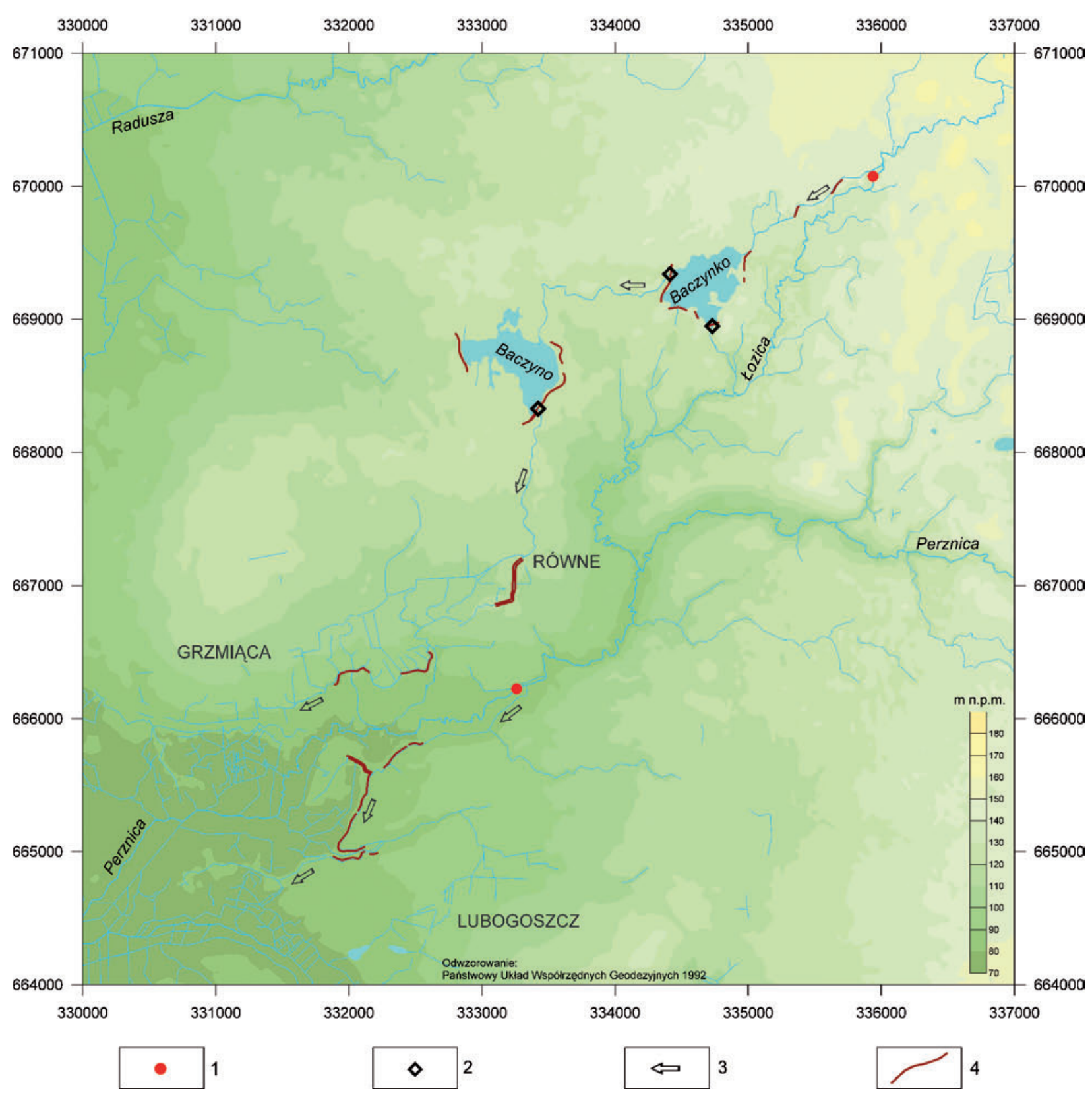

Fig. 2. Transformations of the natural hydrological network in the region of Grzmiąca: 1 - dams, 2 - major weirs, 3 - water transit directions, 4 - earth embankments of ditches and basins

as a result, the impression of the natural character of these lakes. The water outflow from the lakes is regulated by the lock, and headed through the channels and ditches towards the drained meadow of the right bank of Perznica valley, to the east and north of Grzmiąca village. For the purpose of irrigation of fields and meadows that lie along the left side of the Perznica valley, between the villages of Grzmiąca and Lubogoszcz, the waters were swelled to a height of about 4 meters. Then they were directed to the slopes by channels running, with minor drops, along contour-lines.
The drainage activity influenced the changes in the terrain both directly and indirectly. In the area around Grzmiąca about $25 \mathrm{~km}$ of ditches were dug out, and the material recovered from them was used to raise banks. Some irrigation channels that run across the slopes with minimal drops, were surrounded with the earth embankments on one side, and in some sections on two sides. Such embankments, including the ones in Baczyno and Baczynko Lakes, are around $5.5 \mathrm{~km}$ long. The regulatory works on natural sections of the rivers (mainly the Perznica River) led to the 
reduction of river channels and, as a result of the increase of the drop, to increased river erosion (Florek \& Nadaczna 1986, Florek 1993, Florek et al. 2008). Indentation of rivers, caused by increased deep river erosion, has reduced morphological effects of overbank flow within the floodplain terraces (Gonera et al. 1985). Above the dams, a zone of channel bed aggradation has been created, with sedimentation of bottom material and biogenic accumulation, the latter stretched over about $600 \mathrm{~m}$ in the case of the Perznica River. Increased accumulation takes place also in the irrigation canals with low drops. Some of them, devoid of technical supervision, were filled with mineral material of different granulation, and organic sediments.

Significant transformation of the natural water network is present in the Wielatowo Lake basin. Difficulty in water surface runoff from this area is a consequence of the relief. During the phase of meltwater outflow from the dead ice filling the Wielatowo Lake basin, the eastern segment of the 'collar' ridge has been opened. The northern direction of drainage was set by the subglacial channel of the Trzebiechowo Lake and further west, by the Perznica River valley. With the high water level of Wielatowo Lake, specified by the range of the lake plain, the drainage was led to the east, through one of the valley cuttings in the 'collar' ridge, and north, towards the Trzebiechowo Lake. At lower water level, similar to the one present nowadays, the drainage headed east through the Gonne stream, and then the Gwda River. Such situation is shown on the Gilly's map (1789) and the Generalstabskarte map (1855). The detailed analysis of the hydrological network from the 1877 topographic map shows that the surface runoff from the Wielatowo Lake took place not through the rivers, but only through a wetland area: to the east through the Gonne stream, and to the north up to the ponds located near the village of Brzeźno. There has also been a significant change, namely the connection of unnamed, inland lake (German name Glunow See) with the ponds near Brzeźno. The outflow of water from this small lake allowed the $5 \mathrm{~m}$ deep, and over $200 \mathrm{~m}$ long cross-cut through the hill of moraine plateau. These operations were undertaken to reduce the water level in the lake by diverting part of water from the Wielatowo Lake to the Perznica catchment. The drainage works were related to the industrial exploitation of peat in the Kusowskie Bagno marsh, located west of Wielatowo Lake. To the mid 1940s, when the peat mine was still functioning, the outflow of water from Wielatowo Lake was possible both to the east, through the deepened channel of the Gonne stream, as well as to the north, via drained basin ponds near Brzeźno village, and next to Trzebiechowo Lake and the Perznica River. In order to accelerate the outflow, another excavation of approximately $150 \mathrm{~m}$ was made, from the hills of the moraine plateau between Wielatowo Lake and Brzeźno village. The contemporary situation in which the surface runoff from Wielatowo Lake functions, and flows both to the Gwda River, as well as (with much larger runoff), to the Perznica catchment, is largely the result of anthropogenic influence on the river network in this area. Today, the preserved part of the Kusowskie Swamp is a protected nature reserve. For the purpose of peatbog restoration, some weirs in the drainage ditches were implemented to raise the groundwater level and reduce the runoff.

\section{The transformations on the slopes and moraine plateaux}

The drainage activity in the river valleys also allowed drainage of excess water from the depressions located on the slopes and moraine plateaus. Intensification of agricultural land improvement occurred in the second half of the nineteenth century. A dense network of open drainage ditches in the fields was created. The ditches hindered the tillage and occupied a considerable part of the fields, therefore in subsequent years they have been gradually replaced by an underground drainage network. The drainage contributed to the increase of inequality in the outflow of drained areas, such as small drainage basins in the vicinity of Torun, as shown by Niewiarowski et al. (1992). Above all, lowering the groundwater level allowed the entry of crops on previously inaccessible enclaves in the midfield depressions. It enabled the start of the leveling process of the midfield depressions by rapid delivery of sediments from slopes, which was a result of tillage denudation. 


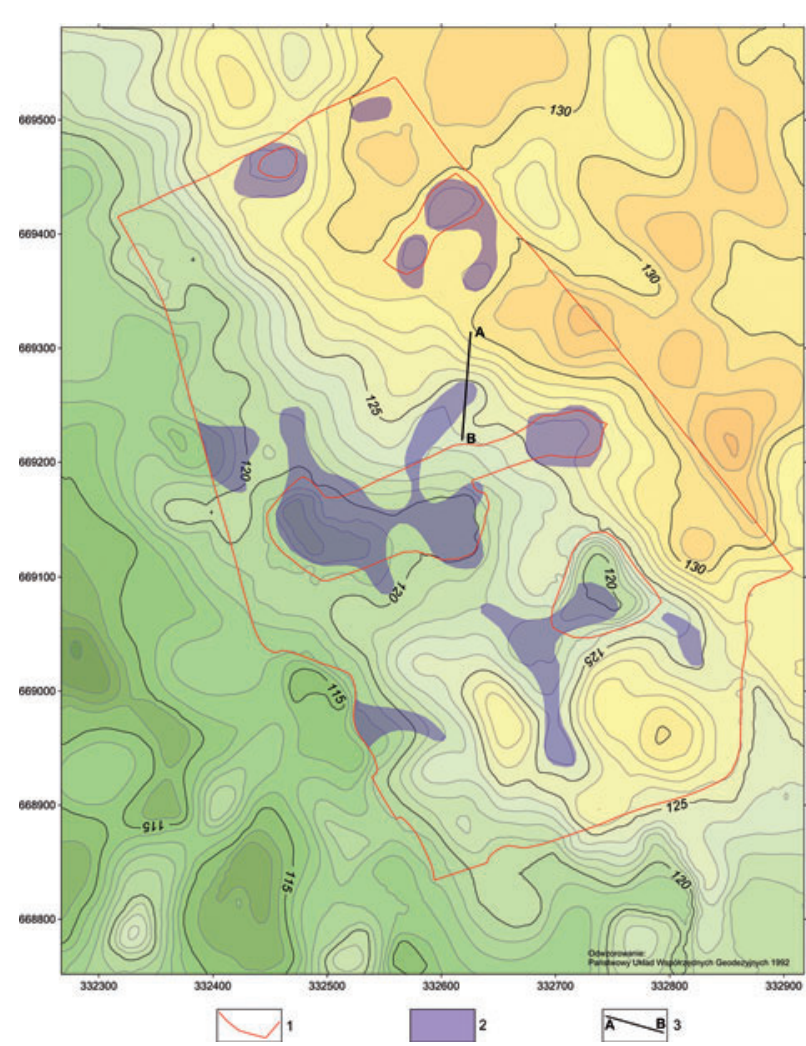

Fig. 3. The test area "Gdaniec Pole": 1 - border of the field and the areas excluded from cultivation, 2 - peat, deposits similar to peat and organic-mineral material under mineral deluvium, 3 - localization of the profile presented in fig. 4

In order to perform the accurate mapping of the contemporary relief, and to diagnose the sediments of the previous relief through lithological features, the detailed measurements were made near the Gdaniec village, within the undulated moraine upland. The measurements showed the presence of numerous fossil field depressions, camouflaged with sandy sediments (Fig. 3). These sediments, mostly with agricultural diamicton texture, were covered by peat, organic peat-like sediments, or dark-colored organic-mineral alluvium. The recognized agricultural diamicton layer reaches up to $150 \mathrm{~cm}$. The spatial extent of discovered fossil depressions generally refers to lowerings in the contemporary relief. They cover $15 \%$ of the surface of the field. So many formerly present depressions with biogenic sediments covered with deluvium, indicate a strong influence of tillage denudation. This process occurs very intensively in Great Poland Lakeland, as noted in

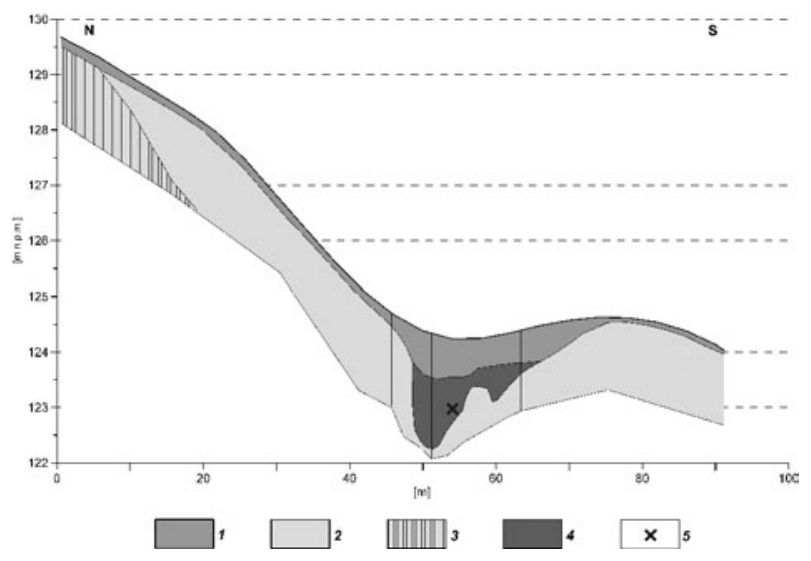

Fig. 4. The topographic-litological profile in the test area "Gdaniec Pole" (in the fig. 3 marked as A-B profile): 1 - accumulation-humus level and agricultural diamicton with sands or slightly loamy sands, 2 - sands of different granulation, 3 - sandy clay loam, 4 - peat and peat rotten in the top, 5 - wooden remains of drains

the study of anthropogenic transformation of soil by Marcinek \& Komisarek (2004).

The detailed identification of sediments in the profile A-B, comprising a fragment of the slope with the fossil depression (Fig. 4) provided information on both lithology and the possible magnitude of accumulation. Over the fossil depression, up to $88 \mathrm{~cm}$ below the ground surface, lies the agricultural diamicton with slightly loamy sand. Deeper, there is a layer of $60 \mathrm{~cm}$ thick sedge peat, poorly decomposed and rotten on top, with numerous fragments of twigs. In this layer, at a depth of $120 \mathrm{~cm}$ below the ground level, wood residues placed horizontally were encountered, and interpreted as the remains of the drains. Assuming that these are preserved traces of the first field drainages, performed in this area since the 1870s, and taking into consideration the sandy overburden of agricultural diamicton on the peat, the estimated average intensity of the filling depression is $7 \mathrm{~mm} \mathrm{a}^{-1}$. Such sedimentation rate of deluvium is characteristic for superstructure of agricultural terraces, and for the filling of midfield depressions with modern, intensive agricultural techniques (Ziemnicki \& Mazurek 1972, Szpikowski 2010), whereas surpasses several times an intensity of aggradation in the historic period (Sinkiewicz 1998, Twardy 2008, Szpikowski 2010). 


\section{Conclusions}

The human interference in the river valleys and anthropogenic changes in natural hydrological systems in the Perznica catchment influenced the transformation of the relief and the intensity of morphogenetic processes directly and indirectly through:

- formation of anthropogenic landforms such as embankments, dams, dykes along the canals, ditches and canals, reservoirs basins, peat workings,

- intensification of bottom and lateral erosion, due to drainage leading to channel straightening, shortening, and the increase of river gradient in certain sections of the valleys, as well as the consequent increase of the amount of the suspended matter leaving the catchment,

- intensification of aggradation processes in the sections of channels above the dams of drainage systems and in the mill-ponds,

- increase of anthropogenic denudation on agricultural lands due to the entering of the crops grown on drained mid-field depressions and valleys, leading to the masking of the original, more diversified relief with deluvial sediments on the slopes, and on the edge of fields, the formation and expansion of agricultural terraces.

\section{References}

BRÜGgemann L.W., 1784. Ausführliche Beschreibung des gegenwärtigen Zustandes des Königl. Preußischen Herzogthums Vor und Hinter Pommern. H.G. Effenbart, Königl. Buchdrucken, Stettin.

Choiński A., 1991. Katalog jezior Polski. Pojezierze Pomorskie. Wyd. Nauk. UAM, Poznań.

CHOIŃSKi A., 1998. Warunki obiegu wody w dorzeczu Parsęty. In: A. Kostrzewski (ed.). Funkcjonowanie geosystemów zlewni rzecznych 1. Środowisko przyrodnicze dorzecza Parsęty, stan badań, zagospodarowanie, ochrona. Wyd. Ucz. Polit. Koszalińskiej, Koszalin, 36-51.

Ciupa T., 2009. Wptyw zagospodarowania terenu na odptyw $i$ transport fluwialny w matych zlewniach na przykładzie Sufragańca i Silnicy (Kielce). The impact of land use on runoff and fluvial transport in small river catchments. Wyd. Uniwersytetu Humanistyczno-Przyrodniczego, Kielce.

DoBRACKA E. \& LEWANDOWSKI J., 2002. Strefa marginala fazy pomorskiej lobu Parsęty (Pomorze Środkowe). In: Plejstocen Pomorza Środkowego i strefa marginalna lobu Parsęty, Sosnowiec, 109-117.
DYnowska I., 1971. Typy reżimów rzecznych w Polsce. Zesz. Nauk. UJ, Prace Geogr., z. 28, Prace Instytutu Geogr., z. 50, Kraków.

FloreK E., FloreK W. \& ŁęcZYŃSKI L., 2008a. Funkcjonowanie zbiorników zaporowych na Słupi jako czynnik rzeźbotwórczy. (Summary: Reservois of the Słupia river as morphogenetic agents). Landform Analysis 7: 12-22.

FLOREK W., 1993. Antropopresja a holoceńskie procesu fluwialne na obszarze środkowego Pomorza i Pobrzeża. The Holocene and contemporery fluvial processes under anthropopresion on the middle part of Pomerania and Baltic coastal region. In: A. Kostrzewski (ed.). Geoekosystem obszarów nizinnych. Polska Akademia Nauk, Kom. Nauk. przy Prez. PAN „Człowiek i Środowisko": 49-60.

Florek W. \& Nadaczna, E., 1986. Zmiany biegu Wieprzy i Parsęty w ciągu ostatnich dwustu lat w świetle analizy materiałów kartograficznych. Bad. Fizj. Pol. Zach., 36 A: $33-52$.

Florek W., Zwoliński Z., ANDRZejewski L., KostrZewSKi A., SMOLSKA E. \& SZMAŃdA J., 2008b. Współczesne procesy kształtujące rzeźbę dolin rzecznych. In: L. Starkel, A. Kostrzewski, A. Kotarba, K. Krzemień (eds). Wspótczesne przemiany rzeźby Polski. IGiGP UJ, Kraków: 292-305.

GaLON R., 1954. Wstępna wiadomość o opracowaniu dotyczącym zanikania jezior w Polsce. (Summary: A preliminary communication on a paper concerning the disappearance of lakes in Poland). Przegl. Geogr., t. XXVI, z. 2: 81-91.

Gilly D., 1789. Karte des Königl. Preus. Herzogthums Vor. und Hinter Pommern nach Speciellen Vermesungen entworfen. von D. F. Sotzmann, Berlin.

Gonera P., KiJOwsKi A. \& ZwolińsKi Z., 1985. Powezbraniowe formy akumulacyjne na terasie zalewowej Warty i Parsęty w świetle analizy zdjęć lotniczych. Fotointerpretacja w Geografii, 8(18), 24-42.

GUTRY-KORYCKA M., 1999. Zlewnia jako geoekosystem dynamiczny. W: A. Kostrzewski (ed.). Funkcjonowanie geoekosystemów zlewni rzecznych 2. Powodzie rzek Przymorza Bałtyku i innych regionów Polski. Uwarunkowania i skutki w środowisku przyrodniczym. Bogucki Wyd. Nauk., Poznań, 17-32.

HeEse T., 1999. Zbiorniki zaporowe Radwi - stan poznania i zagrożenia. In: A. Kostrzewski (ed.). Funkcjonowanie geoekosystemów zlewni rzecznych 2. Powodzie rzek Przymorza Bałtyku i innych regionów Polski. Uwarunkowania, przebieg $i$ skutki w środowisku przyrodniczym. Bogucki Wyd. Nauk., Poznań: 75-79.

KarCZEWSKi A., 1989. Morfogeneza strefy marginalnej fazy pomorskiej na obszarze lobu Parsęty $w$ vistulianie (Pomorze Srodkowe). Morphogenesis of the Pomeranian Phase marginal zone in the Parsęta lobe region in the Vistulian (Middle Pomerania). UAM, Geografia, 44, Poznań.

Kondracki J., 1998. Geografia regionalna Polski. PWN, Warszawa.

KostrZewsKi A., 1986. Zastosowanie teorii funkcjonowania geosystemu do współczesnych środowisk morfogenetycznych obszarów nizinnych Polski Północno-Zachodniej. Spraw. PTPN, 103: 26-28.

KostrZEWSKi A., 1993. Geoekosystem obszarów nizinnych. Koncepcja metodologiczna. (Summary: The geoecosystem of lowlands areas a methodological conception). In: A. Kostrzewski (ed.). Geoekosystem obszarów nizinnych. Polska Akademia Nauk, Kom. Nauk. Prez. PAN „Człowiek i Środowisko", Zakład Narodowy im. Ossolińskich, Wrocław, 11-17. 
Kostrzewski A., Mazurek M. \& Zwolí́ski Z., 1994. Dynamika transportu fluwialnego górnej Parsęty jako odbicie funkcjonowania systemu zlewni. Dynamics of fluvial transport of the upper Parseta River as a response of the catchment system. SGP, Poznań.

KozŁowski S. (ed.), 1994. Atlas zasobów, walorów i zagrożeń środowiska geograficznego Polski. Agencja ReklamowoWydawnicza A. Grzegorczyk, Warszawa.

Lubinus E., 1618. Nova illustrissimi principatus Pomeraniae descriptio cum adjuncta Principum Genealogia et Principum veris et pofiorum Urbium imaginibus et Nobilum Infignibus. ok. 1:24000.

MALINOWSKI B., 2006. Antropogeniczne przemiany krajobrazu ziemi bobolickiej w XX wieku. (Summary: Anthropogenic changes in the landscape of Bobolice area in the $20^{\text {th }}$ century). In: Ochrona przyrody na Pomorzu Środkowym - formy ochrony, monitoring środowiska, edukacja przyrodni$c z a$, Biuletyn nr 5, Towarzystwo Ekologiczno-Kulturalne w Bobolicach, Intro-Druk, Koszalin: 7-23.

MarcineK J. \& KomisAReK, J., 2004. Antropogeniczne przeksztatcenia gleb Pojezierza Poznańskiego na skutek intensywnego użytkowania rolniczego. Anthropogenic transformations of soils of Poznan Lakeland as a results of intensive agricultural farming. Wyd. A.R. w Poznaniu, Poznań.

Niewiarowski W., Celmer T., Marciniak K., Pietrucień C., ProsZeK P. \& Sinkiewicz M., 1992. Przebieg współczesnych procesów denudacyjnych na młodoglacjalnej wysoczyźnie morenowej intensywnie użytkowanej rolniczo, na przykładzie okolic Koniczynki, na północny wschód od Torunia. In: A. Kotarba (ed.). System denudacyjny Polski. IGiPZ PAN, Prace Geogr., 155: 47-67.

PIEŃKOWSKI P., 1996. Przekształcenia oczek wodnych na przykładzie północnej części Równiny Wełtyńskiej. Zesz. Nauk. AR w Szczecinie., Rolnictwo 63: 37-41.

Pietrucień C., 1993. Zmiany hydrologiczne i przestrzenne obszarów podmokłych. In: I. Dynowska (ed.). Przemiany stosunkow wodnych w Polsce w wyniku procesów naturalnych i antropogenicznych. IG UJ, Kraków: 177-205.

Pietrzak M., 2005, Geomorfologiczne podejście do rektyfikacji historycznych map w programie Erdas Imagine. In: A. Kotarba, K. Krzemień, J. Święchowicz (eds). Współczesna ewolucje rzeźby Polski. IGiGP UJ, Kraków: 361-366.

PISKORSKI J., 1990. Kolonizacja wiejska Pomorza Zachodniego w XIII i początkach XIV wieku na tle procesów osadniczych w średniowiecznej Europie. Wyd. PTPN, t. 41, Poznań.
PODGóRSKI Z., 2004. Wpływ budowy i funkcjonowania młynów wodnych na rzeźbę terenu i wody powierzchniowe Pojezierza Chetmińskiego i przyległych części dolin Wisty i Drwęcy. The influence of the construction and functioning of watermills on the relief of the land and surface water of Chetmno Lakeland and the adjoining parts of the Vistula and Drweca valleys. Wyd. Uniw. M. Kopernika, Torun.

RachleWicz G., NieWIarowski W., KostrZeWSKi A. \& SZPIKOWSKI J., 2008. Współczesne procesy i przekształcenia rzeźby obszarów wysoczyznowych i równin sandrowych strefy młodoglacjalnej. In: L. Starkel, A. Kostrzewski, A. Kotarba, K. Krzemień (eds). Wspótczesne przemiany rzeźby Polski. IGiGP UJ, Kraków: 76-285.

SinKIEwicz M., 1998. Rozwój denudacji antropogenicznej w środkowej części Polski pótnocnej. The development of anthropogenic denudation in central part of northern Poland). Red. i uzupełnienia W. Niewiarowski, Wydaw. UMK, Torun.

SzPIKOWSKI J., 2010. Antropogeniczne przeksztatcenia rzeźby zlewni Perznicy w neoholocenie (Pojezierze Drawskie, dorzecze Parsety). Anthropogenic relief changes of Perznica catchment in the Neoholocene (Drawskie Lakeland, river Parseta catchment. Seria Geografia nr 91, Wyd. Nauk. UAM, Poznań.

SzultKa Z. 2003. Próby reform wsi i ożywienie gospodarcze domen w pierwszej połowie XVIII i początkach XIX wieku. In: G. Labuda (ed.). Historia Pomorza. Tom II: do roku 1815. Część 3: Pomorze Zachodnie w latach 1648-1815. Wyd. Poznańskie, Poznań, 511-566.

Twardy J., 2008. Transformacja rzeźby centralnej części Polski Środkowej w warunkach antropopresji. Wyd. Uniw. Łódzkiego, Łódz.

WodziczKo A., 1947. Stepowienie Wielkopolski. Prace Kom. Mat.-Przyr. PTPN, Poznań.

ZIEMNICKI S. \& MAZUREK T., 1972. Zastosowanie mechanicznego przemieszczania ziemi $\mathrm{w}$ melioracjach przeciwerozyjnych. Zesz. Probl. Post. Nauk Rol., 130: 129-144. 